\title{
Therapeutic Theodicy? Suffering, Struggle, and the Shift from the God's-Eye View
}

\author{
Amber L. Griffioen \\ Department of Philosophy, University of Konstanz, 78457 Konstanz, Germany; amber.griffioen@uni-konstanz.de \\ Received: 26 February 2018; Accepted: 24 March 2018; Published: 27 March 2018 \\ check for \\ updates
}

\begin{abstract}
From a theoretical standpoint, the problem of human suffering can be understood as one formulation of the classical problem of evil, which calls into question the compatibility of the existence of a perfect God with the extent to which human beings suffer. Philosophical responses to this problem have traditionally been posed in the form of theodicies, or justifications of the divine. In this article, I argue that the theodical approach in analytic philosophy of religion exhibits both morally and epistemically harmful tendencies and that philosophers would do better to shift their perspective from the hypothetical "God's-eye view" to the standpoint of those who actually suffer. By focusing less on defending the epistemic rationality of religious belief and more on the therapeutic effectiveness of particular imaginings of God with respect to suffering, we can recover, (re)construct, and/or (re)appropriate more virtuous approaches to the individual and collective struggle with the life of faith in the face of suffering.
\end{abstract}

Keywords: anti-theodicy; theodicy; suffering; epistemic injustice; problem of evil

Then he said, "You shall no longer be called Jacob, but Israel, for you have striven with God and with humans, and have prevailed". -Genesis 32:28

The problem of human suffering can, from a purely theoretical standpoint, be understood as one formulation of the classical problem of evil, which calls into question the compatibility of the existence of a perfectly good (all-knowing, all-powerful) God with the extent to which human beings encounter and undergo positive suffering. ${ }^{1}$ In the context of analytic philosophy of religion, the fact of (what appears to be significant and gratuitous) human suffering has been presented either as logically inconsistent with the existence of the God of classical theism or as an evidential consideration counting heavily against the probability of that Being's existence or perfection. With respect to the role that suffering plays in these arguments, there are various formulations of both problems, ranging from why human beings suffer at all to why there is not less suffering than there is to why some individuals should suffer horrendous evils or undergo destructive suffering of the kind that leads them

1 I use the formulation 'positive suffering' here-not to indicate that there is anything "positively valenced" about the experience itself, nor that there is anything about it that is "good" for the agent who undergoes it—but rather to distinguish the term from the somewhat antiquated, more neutral use of 'suffer', meaning simply to passively undergo, tolerate, or otherwise allow something, as in the case of Christ's injunction to "suffer the little children to come unto me and forbid them not" (Luke 18:16). In what follows, then, the instances of positive suffering to which I refer should be understood as generally negatively-valenced in some relevant way (even if they should turn out to be instrumentally necessary or "good" for the subject in some other way). Still, although I focus primarily on subjective, experiential suffering in this paper, I leave it open as to whether one could suffer positively without being able to reflectively call on some particular subjective experience or set of experiences, perhaps because one is not aware that one's experience constitutes an instance of suffering or because one does not have the hermeneutical tools to understand—and hence "appropriately" experience—one's own suffering as suffering (cf., e.g., the discussion of hermeneutical injustice in Fricker 2007; cf. also fn. 10 below). 
to question the very value of their lives as a whole. ${ }^{2}$ Yet (although one might not think it from much of the philosophical literature) the problem of suffering neither begins nor ends on the theoretical level. Insofar as suffering - especially in its more horrific and traumatic manifestations-is something that strongly affects the meaning we attach to both our individual lives and our collective identities, the problem is deeply, and perhaps most fundamentally, an existential one. Further, in those traditions in which God is presented as someone to whom creation is supposed to be essentially bound via a relation of care and with whom creatures are potentially joined in a relationship of love, the problem becomes both personal and intersubjective. ${ }^{3}$

For this reason, some critics have proposed that analytic approaches which treat the problem of suffering solely as another speculative puzzle about the nature of a purportedly perfect being fail in some relevant way to take the concrete suffering and oppression of particular human beings seriously. ${ }^{4}$ Such methodological "anti-theodicists" often claim that the theodical strategy itself displays a kind of detached moral insensitivity or "blindness" to genuine human suffering, insofar as it attempts to abstractly transform that suffering into a necessary evil that serves some "greater" purpose or good-be it the realization of the best of all possible worlds, the creation of opportunities for virtuous "soul-making" or "intimacy" with the divine, the punishment of bad acts of human free will, or the result of some divine reason we cannot fathom given our limited cognitive capacities. ${ }^{5}$ Such justifications of God, the anti-theodicist claims, might even add to the amount of harm in the world as opposed to alleviating it, insofar as they get God "off the hook" at the cost of failing to recognize suffering as inherently bad or condemnable. As Toby Betenson (channeling Nick Trakakis) puts it: "[I]n responding to the problem of evil by constructing a justification of God's permission of terrible evil, theodicies think the morally unthinkable, they sanction the unsanctionable, they justify the unjustifiable; theodicies render 'ok' what should not be rendered 'ok'. In short, 'Theodicies mediate a praxis that sanctions evil'" (Betenson 2016, pp. 63-64). ${ }^{6}$

I share the concerns of many anti-theodicy scholars and activists and have for some time been dissatisfied with way in which genuine human suffering is treated in theodical discourse. More recently, I have come to suspect that many (though certainly not all) of the theodicies in mainstream analytic philosophy of religion stem from a place of relative privilege, in which the dominant voices represent those philosophers who are cognitively and emotionally in a position to be able to distance themselves from particular evils and traumata in a way sufficient to allow them to consider suffering more abstractly and to ask how it might be necessary for (or at least as conducive to) promoting some further divine end. And while the ability ${ }^{7}$ to academically "dissociate" oneself in such a way-e.g., in the interest of objectivity - can be beneficial in scholarly discourse, I worry that, in the case of theodicy, the persistent attempt to take up a "God's-eye view" of suffering in the service of justification of the divine may do more harm than good, both to the character of the academic theodicist herself and to those who are undergoing or have undergone existentially significant suffering. ${ }^{8}$ It may be

2 The late Marilyn Adams defines horrendous evils as "evils the participation in (the doing or suffering of) which gives one reason prima facie to doubt whether one's life could (given their inclusion in it) be a great good to one on the whole" (Adams 1989, p. 299). In a related (though importantly separate) vein, Michael Stoeber understands destructive suffering as "suffering which is and always remains non-redemptive for the person. It has no [positive] spiritually transformative impetus or context for the victim in question" (Stoeber 2005, p. 61).

3 Cp. Eleonore Stump's claim that "the problem of suffering is, in a sense, a question about interpersonal relations, insofar as the problem has to do with possible morally sufficient reasons for God, an omnipotent, omniscient, perfectly good person, to allow human persons to suffer as they do" (Stump 2010, p. 61, my emphasis).

4 Cf., for example, Betenson (2016), Trakakis (2008), Phillips (2004), Surin (1986), et al. See also Graper Hernandez (2016) and Bar On (2003) for worries concerning certain forms of philosophical abstraction with respect to discussing concrete suffering.

5 This, of course, represents only a few of the many theodical approaches found in the philosophical literature.

6 Betenson takes the final quote from Trakakis (2008), pp. 28-29.

7 One might even call it a "luxury".

8 These categories may and do overlap, of course. 
morally harmful, insofar as it contributes to the vicious tendency many of us already have to ignore the suffering of others and promotes the kind of moral insensitivity and blindness mentioned above, the effects of which may have a negative or even re-traumatizing effect on those who actually suffer. It may be epistemically harmful, insofar as it ignores or downplays credible sources of testimony in favor of explanations aimed at defending and protecting divine perfection at all costs, which may lead to the development of distorted beliefs and narratives about what it is and what it means to suffer. ${ }^{9}$ Bringing these two threads together, philosophical theodicy may serve to propagate a form of epistemic injustice that both fails to take seriously the testimony of certain agents as credible sources of knowledge concerning human suffering and constructs an insular theological framework from which many such agents are no longer able to recognize their own lived experience and suffering. ${ }^{10}$

Especially in the context of 20th-century analytic religious epistemology, which overwhelmingly concerned itself with defending the rational permissibility of religious belief in the face of secular and atheist challenges to the contrary, theodicies have tended to be evaluated on the basis of their effectiveness in countering the challenges posed by contemporary forms of the problem of evil and preserving the rationality (or non-irrationality) of religious belief. Indeed, although sometimes mistakenly referred to as "justifications" or "defenses" of God, the function of theodicy in these contexts is ultimately aimed at justifying or defending theistic belief. ${ }^{11}$ Yet if the limited doxastic profits of the theodical strategy (the output of which is always hypothetical) are outweighed or undermined by the harms, both epistemic and moral, it may cause to actual victims of horrendous suffering and those desiring to act to counter it, what function, if any, is left for theodicy of this kind to serve?

While my proposal in what follows will do little to satisfy the classical theist who is hell-bent on defending the rationality of religious belief against its polemical detractors, I think the discipline of analytic philosophy of religion might do well to shift its attention somewhat from the theoretical God's-eye view to that of the existential and religious situations of those who really suffer-and from the epistemic status of religious belief to the practical situatedness of lived experience. For although suffering is a universal problem, it can only be responded to in the particular. The fact of suffering is shared, but its manifestations are irreducibly specific (even where they are collective). Thus, we might do better to think less about the rhetorical gains achieved by particular theodicies and more about their therapeutic effectiveness for those persons struggling with faith in the face of suffering. This suggestion does not by any means represent a new approach, ${ }^{12}$ but it is something that deserves renewed and more extensive attention. It is intended merely to provide a reminder-if not a balance or corrective- to the dominant approach taken by analytic philosophy of religion.

A modest version of the therapeutic approach suggests only a shift in perspective-the question becoming less about how well a generalized characterization of suffering can "square" the divine attributes of classical theism with the extent of human suffering and more about how practically valuable our theologically- and scripturally-grounded imaginings of God and God's relation to creation might be with respect to reconciling the life of faith with the very real effects of particular suffering.

9 For a further perspective on the moral and epistemic harmfulness of the attempt at a God's-eye perspective in philosophy of religion, cf. Anderson $(2005,2012)$.

10 Miranda Fricker (2007) refers to these two forms of epistemic injustice as testimonial and hermeneutic injustice, respectively.

11 While a distinction is sometimes made in the literature between defenses and theodicies proper, I am not sure the distinction is as relevant in the context of the anti-theodical charge. Perhaps those providing defenses are somewhat "humbler" in their epistemic claims, but they strike me as still likely to promote harms of the type pointed to by the anti-theodicist, even if such accounts are merely pointing to logical possibilities or stories that are, as Peter Van Inwagen (2006) puts it, true "for all we know". Indeed, insofar as such defenses might be asking us to imagine possible worlds that are (for all we know) quite distant from our own, they may end up doing more harm than straightforward theodicies by removing the subject imagining such worlds even further from the very real suffering in the actual world.

12 Indeed, this should not be viewed as a universal condemnation of all analytic treatments of the problem of suffering. I think some analytic approaches to the problem of suffering, e.g., those by philosophers like Marilyn Adams and Eleonore Stump, do try to take the concrete suffering of individuals seriously and grapple with the problem in ways that demonstrate both humility in the face of the problem and a sensitivity to the need for a therapeutically effective response. Whether their approaches actually constitute such a response I leave open here. 
A slightly more radical understanding of what I am suggesting proposes a genuine reappropriation of the term 'theodicy' to signify, not the various presumptive, quasi-objective answers to the problem of suffering from the God's-eye perspective, but rather the of the dynamic, diachronic, and irreducibly diverse struggle by which human beings wrestle with the problem of lived faith, the experience of suffering, and the witnessing to evil. From a philosophical standpoint, what is needed is a deep and meaningful analysis of the Jacob-esque process by which we grapple with the divine and with each other in the face of human suffering and the ways in which we may thereby be transformed, for better or, in some cases perhaps, for worse.

$$
* * *
$$

The perspectival shift I am suggesting, in which theodicy is evaluated therapeutically rather than (merely) epistemically, calls for innovative ways of thinking about the problem of suffering. It asks us to relinquish our attempts to generate justificatory reasons from the perspective of the abstracted divine (or, minimally, to refrain from thinking that if we occupied the God's-eye view, we would be in possession of such reasons) in favor of imaginatively taking up the standpoint of Job in his concrete suffering. Of course, innovation is sometimes less a matter of coming up with something entirely novel and more about finding creative ways to apply historically relevant and culturally meaningful ideas that already speak to us and may provide fruitful avenues for continued thought in the present day. Such an approach is exactly what Nehama Verbin adopts in a recent article on the problem of suffering, in which she discusses three ways of engaging with the figure of Job-namely, those proposed by Maimonides, Kierkegaard, and Verbin herself ("inspired by the great Hasidic rabbis", Verbin 2017, p. 388) —and the ways in which these approaches understand the situation of Job (who spoke "correctly" of God ${ }^{13}$ ), his suffering, and how it is (or may be) defeated.

Invoking a term from Kierkegaard, Verbin characterizes her three philosophical re-figurings of Job as different "knights of faith". Maimonides' Job, she claims, appears as a knight of wisdom, whose suffering represents a deep form of ignorance-and who transcends his pain via a non-propositional acquisition of mystical wisdom through contemplation of the divine (cf. pp. 384-85). Kierkegaard himself, in contrast, presents Job as a knight of loving trust, who recognizes the "central role" that suffering plays in the life of faith (p. 385). This Job, Verbin claims, recognizes that the life of faith may actually increase one's suffering, insofar as faith in the face of suffering entails a paradoxical and dissonant struggle in which the individual both "breaks with the world, and, at the same time, remains within it" (p. 386). He thus does not cease to suffer but nevertheless transforms his suffering: he "over[comes] his loss by hanging onto God" (p. 388). Finally, Verbin herself construes Job as a knight of protest - a figure of resilience, who "defeats the suffering of an injustice [ ... ] by naming the injustice an injustice, by resisting it, by protesting against it, and by refusing to be reconciled with it" (p. 390). This third Job may forgive God, but he remains unwilling or unable to be reconciled with the divine.

Ultimately, Verbin argues that despite their differences and seeming incommensurability, "all three Jobs [ ... ] may be embraced, both from a philosophically descriptive perspective as well as from a religiously committed one" (Verbin 2017, p. 382). They can be embraced from the standpoint of philosophical analysis, she argues, insofar as each gives voice to various manifestations of faith-based responses to suffering that themselves "render perspicuous the 'grammar' of 'faith"' (p. 391) and reveal it as fundamentally multifaceted. They can also be embraced, she claims, from a religiously committed standpoint-not in the sense of cognitively assenting to each of the propositions these approaches endorse, but rather in the sense of "embracing, or at least seriously considering, the values that each of them embodies" (p. 383). Such values may not necessarily be pursuable simultaneously,

13 The reference here is to Job $42: 7-8$. 
but they serve to complement rather than to contradict one another, and their diversity "serves to unmask the different shadows that lurk behind each of our paradigms of perfection" (p. 391-92).

Still, from a therapeutic standpoint, the approach of each of these "knights" brings with it serious potential pitfalls and dangers. For example, characterizing someone's suffering as merely a matter of some "ignorance" that needs to be corrected threatens to fail to take the standpoint of the suffering individual seriously and has the potential to contribute to the testimonial injustice society often inflicts on victims. Likewise, suggesting that those who suffer horrendous evils remain in (but not of) the world by "hanging onto" an unfathomable God might sound like asking a victim of abuse to return to her abuser. ${ }^{14}$ Finally, encouraging unwavering protest or moral hatred of God's very self (as opposed, for example, to God's actions) may close oneself off to the possibility of forgiveness, reconciliation, or divine intimacy in ways that merely serve to add to one's suffering, as opposed to overcoming it. ${ }^{15}$ Nevertheless, I think that Verbin's pluralistic approach to Job's process of overcoming also demonstrates three ways in which theodicy re-construed as a dynamic grappling with the problem of suffering may be therapeutically valuable—at least if these three historical approaches are adapted and appropriated in certain meaningful ways. Indeed, each of her three knights presents those who suffer with a way of being reoriented with respect to their suffering-whether it be cognitively, affectively, or volitionally.

For example, although it may be extremely damaging to construe someone who has undergone destructive suffering as merely "lacking" in some relevant knowledge or wisdom, the possession of which would miraculously "fix" her, there is a sense in which, from a purely descriptive standpoint, traumatic suffering itself is characterized by a lack of comprehension (and/or comprehensibility). Insofar as traumatic events often cause a radical break in an individual's self-understanding-an interruption in her self-narrative resulting in an inability to be able to make sense of herself and the world around her-the epistemic consequence of such traumata may be a form of suffering that has a lack of understanding at its very core. ${ }^{16}$ In this sense, certain forms of therapeutic re-orientation may be helpful, in which, e.g., the repeated reliving of a traumatic event (and the re-traumatizing effect it may have on the individual) is verbally articulated and cognitively transformed into a coherent remembering with a narrative structure that the agent can incorporate into a more intelligible autobiographical story (cf., e.g., Schauer et al. 2011, p. 3). In this sense, one's reflections on the divine nature and the role one assigns it in the story of one's suffering can bring meaning to one's cognitive, affective, and volitional chaos. It may also assist in promoting a kind of acceptance-not, perhaps, of the trauma or suffering one has undergone, but of the fact that one will always in some sense occupy a space that others lacking such a narrative will not. One may come to accept that one will, like Kierkegaard's Job, always have one foot in the world and one foot outside it. In other words, like the knight of loving trust, one may have to give oneself over to a narrative that affirms a break with the world, precisely in order to remain within it.

Yet neither of these approaches requires that the role God plays in such a narrative be one that absolves the divine of its role in one's suffering. The narrative contemplation of the divine by the knight seeking wisdom may, as with Verbin's Job, lead her to the conclusion that she has "suffered an unjust divine assault against [her], a divine abuse" (Verbin 2017, p. 389). Likewise, although such a narrative

14 For more on the question of intimacy and abuse with respect to the divine, cf. Michelle Panchuk (2017) response to Michael Harris' divine intimacy theodicy.

15 Importantly, however, as I discuss presently, I think there may be cases in which such moral hatred is both unavoidable and warranted, and where reconciliation is impossible. Verbin takes this (rightly, I think) to be the case with Job and other "victims of bad intimacy", whose silence reflects the irreparable distance from God and "reveals courage, inner strength, and an uncompromising commitment to justice" (p. 390). Verbin's Job supereragatorily overcomes his resentment by forgiving God and "conduct[ing] a dialogue with the humiliating message that is conveyed by his assault and reject[ing] it" (p. 389), but he does not thereby seek to reconcile himself to the unrepentant divine being.

16 For a discussion of the ways in which "events that threaten, violate, or destroy" a subject's "core assumptive explanatory worldviews", cf. Everly and Lating (2004), pp. 36ff. For a further philosophical discussion of the cognitive and affective repercussions of her own traumatic experiences, cf. Brison (2003). 
may (in some cases) serve to transform suffering, making it more manageable to bear, the trust required of such a knight might not be that of placing loving trust in God, but rather that of coming to trust herself by trusting her own narrative-by "hanging onto" (but by no means justifying or absolving) a God who is a perpetrator. In this way, then, there is always room for the knight of protest, who-in the burdensome wisdom unfairly inflicted upon her through her experience of suffering, and with renewed trust in herself-asserts her theodical narrative precisely by refusing to be reconciled with the kind of God who hurts the objects of its "love".

Importantly, each of the three approaches Verbin discusses can also be adopted by those in positions of privilege in the service of combatting and alleviating such suffering and standing in solidarity with those who experience such evils. Yet here we must be careful. The sometimes unbridgeable gap in the standpoint of these two parties may also demand a difference in the ways knightly wisdom, loving trust, and protest are virtuously and/or therapeutically exemplified. The struggles of those who suffer from, e.g., poverty, disease, or violence, are not the same as the difficulties encountered by those who witness (to) them from the outside, and thus what counts as wisdom, trust, or protest in these cases may crucially depend on factors of proximity and perspective. The immediateness and reality of evil to those who suffer first-hand is one that is not easily conveyed to second-hand parties. Moreover, characteristic of many individuals and groups in positions of power and privilege is a sense of apathy with respect to the genuine suffering of others-a socially-promoted "inability to suffer", as German theologian Dorothee Sölle puts it, in which "the avoidance of suffering as a goal so dominates people that the avoidance of all relationship and contact [with suffering] itself becomes the goal. [ ... ] They experience suffering, but they are 'content with it': it doesn't touch them. They have no language and no gestures to deal with suffering. It changes nothing. They learn nothing from it" (Sölle 1973, p. 50) ${ }^{17}$ What is lacking in such persons, Sölle thinks, is both the ability to recognize or identify suffering (both in others and in oneself) and the possession of a sensibility or sensitivity for that suffering, especially the suffering of others. This "lack of consciousness" and "numbness" (pp. 52-53) with respect to suffering reflects a cognitive and affective deficiency that produces a kind of inability to perceive things as they really are and an associated motivational paralysis. Thus, the apathy of the privileged is both epistemic and moral: a selective blindness to the severity of suffering and a weary unwillingness to fight oppression where it occurs.

Here, again, we might recognize the harms that may be perpetrated by overly abstracted, God's-eye-view theodical reasoning. Yet Verbin's approach also provides us with the tools to combat these ills. While apathy with respect to suffering is ultimately a problem of the will, the volitional issue cannot be addressed without a commitment to taking the suffering of others seriously, and this can only be achieved by addressing the cognitive and affective deficiencies that ground such apathy. This will involve an attempt at understanding the depth of others' suffering, even if one cannot oneself experience it. Yet such comprehension is not possible without taking seriously the testimony of suffering persons-that is, without lending them the kind of sympathetic trust and credibility that we would extend to those with whom we stand in closer emotional proximity. And when we begin to take such testimony as a credible source of knowledge-when we trustingly listen rather than presumptively speaking-we may be moved to resist such evil and to stand together with and for those who suffer. Here, the knights of wisdom, loving trust, and protest are transformed into a knight of compassion-a knight who, although perhaps unable to feel "with" or "into" those who suffer, feels alongside them in a way ("com-passio") that demonstrates understanding, solidarity, and a commitment to resistance.

17 All quotes and phrases from Sölle are my translation. 
One may wonder here where God has gone on such an approach. Can a therapeutic theodicy grapple with faith in the face of suffering without thereby sacrificing the divine-without making God disappear? Certainly there is much more to be said on this point. For now, I can only leave the reader with the following reflections:

First, a shift to the perspective of Job necessarily "disappears God" by taking divine withdrawal, hiddenness, and absence seriously. Indeed, this kind of theodical grappling will always have a God-who-withdraws at its center. Where Job is met with divine silence in the face of his suffering, he may feel a withdrawal of God's very presence. Where he experiences God's overwhelmingly immanent power (think here of the "gird up your loins" speech from the whirlwind ${ }^{18}$ ), he might feel a withdrawal of or alienation from the presence of divine love. These experiences of absence, withdrawal, and alienation are important aspects of the dynamic theodical experience-they "touch" the individual where it hurts and "carve" her at her metaphysical and spiritual joints in ways that forever change her Self and her relation to the world around her. However, in this sense, God is also always present in the discourse of theodical struggle, even where that presence is marked by a form of felt absence-for perceiving something as absent is not identical to its simply failing to be perceived as present. ${ }^{19}$

Second, the God in therapeutic theodicy is also "absent" insofar as it is a God who awaits imaginative and narrative re(dis)covery. While, from a theological standpoint, the transcendence and inexplicability of the divine idea may put God out of the reach of human understanding, the dynamic struggle of theodicy must wrestle with the way we imaginatively represent God in the life of faith on the ground and what these representations mean for how we react and respond to suffering in the world. What do our imaginings of God convey about the way we understand the world and our relationships to each other? How do certain religious concepts and narratives serve to reinforce oppressive structures and practices? How are those persons whom religion should afford comfort and protection affected by these imaginings? And how might we adapt or complicate our concepts of and narratives involving God to appropriately address those who suffer? Modern philosophical theodicy sacrificed Job on the altar of classical theism. Postmodern philosophical theology slew the God of classical theism on the battlefield of anti-metaphysical transcendence. Perhaps one central task of an analytic philosophy of religion for the 21st century is to turn its careful enquiry to the utter immanence of real human suffering, to recover the perspective of a Job and the tenacity of a Jacob, in order to locate theologically fruitful imaginings of a metaphysical God before whom we can sing and dance ${ }^{20}$ but with whom we also can wrestle face to face-a God with whom we can earnestly struggle and against whom we can, perhaps, even loudly protest. ${ }^{21}$

Conflicts of Interest: The author declares no conflict of interest.

18 Cf. Job 38.

19 For more on experiences of absence, cf. Farennikova (2013).

20 For competing takes on classical theist imaginings of the divine, cp. Martin Heidegger's complaint that, before the metaphysical "god of philosophy [... ] the causa sui, "man can neither fall to his knees in awe nor can he play music and dance before this god" (Heidegger 1969, p. 72) and Marilyn Adams' retort that the idea "that we cannot sing and dance before the first cause fails to take seriously Who the first cause really is" (Adams 2014, p. 12).

21 Many thanks to Jill Graper Hernandez for encouraging me to write the essay that became this article and for her great patience throughout the various stages of its conception. Thanks also to my seminar students from "Klassischer Theismus und die religiöse Imagination": Many of the ideas that find their expression here were cooked up in the context of our discussions together. Finally, thank you to two anonymous reviewers for their thoughtful and constructive feedback. 


\section{References}

Adams, Marilyn McCord. 1989. Horrendous Evils and the Goodness of God. Aristotelian Society Supplementary Volume 63: 297-310. [CrossRef]

Adams, Marilyn. 2014. What's Wrong with the Ontotheological Error? Journal of Analytic Theology 2: 1-12.

Anderson, Pamela Sue. 2005. What's Wrong with the God's Eye Point of View. A Constructive Feminist Critique of the Ideal Observer Theory. In Faith and Philosophical Analysis. The Impact of Analytical Philosophy on the Philosophy of Religion. Edited by Harriet A. Harris and Christopher J. Insole. Burlington: Ashgate, pp. 85-99.

Anderson, Pamela Sue. 2012. Re-Visioning Gender in Philosophy of Religion. Reason, Love and Epistemic Locatedness. Burlington: Ashgate.

Bar On, Bat-Ami. 2003. Terrorism, Evil, and Everyday Depravity. Hypatia 18: 157-63. [CrossRef]

Betenson, Toby. 2016. Anti-Theodicy. Philosophy Compass 11: 56-65. [CrossRef]

Brison, Susan J. 2003. Aftermath. Violence and the Remaking of a Self. Princeton: Princeton University Press.

Everly, George S., and Jeffrey M. Lating. 2004. Personality-Guided Therapy for Posttraumatic Stress Disorder. Washington: American Psychological Association.

Farennikova, Anna. 2013. Seeing Absence. Philosophical Studies 166: 429-54. [CrossRef]

Fricker, Miranda. 2007. Epistemic Injustice. Power and the Ethics of Knowing. Oxford: Oxford University Press.

Graper Hernandez, Jill. 2016. Early Modern Women and the Problem of Evil. Atrocity \& Theodicy. London: Routledge. Heidegger, Martin. 1969. Identity and Difference. Translated by Joan Stambaugh. New York: Harper \& Row.

Panchuk, Michelle. 2017. Does Violence Foster (the Right Kind of) Intimacy? Response to Michael Harris' “But Now My Eye Has Seen You': Yissurin Shel Ahavah as Divine Intimacy Theodicy". Edited by Association for the Philosophy of Judaism (Symposium). Available online: http:/ / www.theapj.com/event/symposium-on-michael-harriss-but-now-my-eye-has-seen-youyissurin-shel-ahavah-as-divine-intimacy-theodicy-the-torah-u-madda-journal-172015/ (accessed on 15 February 2018).

Phillips, Dewi Zephaniah. 2004. The Problem of Evil and the Problem of God. London: SCM Press.

Schauer, Maggie, Neuner Frank, and Elbert Thomas. 2011. Narrative Exposure Therapy. A Short-Term Treatment for Traumatic Stress Disorders, 2nd ed. Göttingen: Hogrefe \& Huber.

Sölle, Dorothee. 1973. Leiden. Stuttgart: Kreuz Verlag.

Stoeber, Michael. 2005. Reclaiming Theodicy. Reflections on Suffering, Compassion and Spiritual Transformation. New York: Palgrave Macmillan.

Stump, Eleonore. 2010. Wandering in Darkness. Narrative and the Problem of Suffering. Oxford: Oxford University Press. Surin, Kenneth. 1986. Theology and the Problem of Evil. Oxford: Basil Blackwell.

Trakakis, Nick. 2008. The End of Philosophy of Religion. New York: Continuum.

Van Inwagen, Peter. 2006. The Problem of Evil. Oxford: Clarendon Press.

Verbin, Nehama. 2017. Three Knights of Faith on Job's Suffering and its Defeat. International Journal of Philosophy and Theology 78: 382-95. [CrossRef]

(C) 2018 by the author. Licensee MDPI, Basel, Switzerland. This article is an open access article distributed under the terms and conditions of the Creative Commons Attribution (CC BY) license (http:/ / creativecommons.org/licenses/by/4.0/). 